\title{
Characteristics and Prediction of Simultaneous Flow Over Broad-Crested Weirs and Through Culverts
}

\author{
Mahmoud Sami Mohamed \\ Associate Professor, Dept. of Irrigation and Hydraulics, . \\ Faculty of Engineering, Ain shams University, Cairo, Egypt.
}

\begin{abstract}
The problem of culvert overtopping with water is investigated. In this case, where the culvert cross sectiosal area is not sufficient to drain the incoming flood, the ordinary solution is either to replace the old culvert with a bigger capacity one or to add new vents to the original. An alternative solution is to use the top of the existing culvert as a broad-crested weir and modify (raise) the road approaches to act like an Irish Road.
\end{abstract}

An experimental study has been conducted to simulate the overtopped flow case. In this case a part of the flow will go through the culvert vents and the rest will overtop it. The flow depth at the downstream side is taken greater than the culvert height (submerged flow). The characteristics of these simultaneous flow cases are analyzed. The effect of flow and geometrical parameters of the structure are presented and explained. Discinarge prediction model has been developed by means of multiple linear regression technique. The results of the developed model have agreed with an independent data set.

Keywords: Open channel hydraulics, Hydraulic structures, Discharge measurement structures, Flood drainage, Culvert, Broad-crested weir.

\section{Introduction}

Culverts and broad-crested weirs are hydraulic structures that could be used for measuring the flow rate in open channels. The characteristics of flow through culvert are very complicated because they are controlled by many variables including the entrance geometry, slope, roughness, size, approach and tailwater conditions. The flow through culverts may be partly or completely full. In the former case, the culvert flow is treated as open channel flow while the later case, the flow is dealt as closed conduit flow. Closed conduit may occur even when the outlet is not submerged when the culvert is sufficiently long to be treated as

hydraulically long culvert. This study concerns with the flow through culvert when both inlet and outlet are submerged. Classifications of culvert flow are treated in Chow (1959) and in more details in Herschy (1978) and French (1985). Comprehensive investigation on culvert for discharge measurements may be found in Benson (1968) and Bodhaine (1968). Early studies on the flow through different pipe and box culverts are due to Yarnell et al. (1926). Mavis (1942) tested the flow through a round smooth pipe culvert. Corrugated and concrete pipe culverts were tested by Straub and Morris (1950a,b,c) and by Straub et al. 
(1953a,b). Standard box culverts were tested by Shoemaker and Clayton (1953). The hydraulic behavior of the commonly used pipe culverts was conducted at the United State Bureau of standards as reported by French (1955, 1956 and 1957). Carter (1957) prepared rough design charts to distinguish between hydraulically short and hydraulically long culverts. $\mathrm{Li}$ and Patterson (1956) gave a reasoning for self priming hydraulically short culverts with submerged inlet to flow full. They mentioned that the water rises to the top mainly due to the formation of the hydraulic jump or the backwater effect at the outlet or due to a standing surface wave developed inside the culvert barrels.

On the contrary to the flow through culvert, the flow over weirs is simple and the structure itself is one of the simplest measurement device with the advantage of easy construction, easy installation and structure stability. However, broad-crested weirs may be less accurate in measuring flow rate compared to other accurate devices because of the variable value of the discharge coefficient. British Standards Institute (1965) and USBR (1967) could be consulted for the specification of broad-crested weirs and installation procedures for accurate measurements.

Investigations of free and submerged flow over broad-crested weir were done by Woodburn (1932), ElKateb (1974), Bos (1976), Bos et al. (1984), French (1986) and Ramamurthy et al. (1988). The features of the two dimensional free flow over weirs of rectangular cross section with sharp as well as streamlined corners were presented by Surya Rao and Shukla (1971) based on an experimental study.
Flow separation at the upstream edge of a square edged broad-crested weir was analyzed by Moss (1972). Rao and Rao (1973), Replogle (1978), Ackers et al (1978) and Swamee (1988) studied the broad-crested from discharge coefficient point of view in order to provide empirical expressions for the discharge coefficient. Hager and Schwalt (1994) investigated experimentally the flow features over biroad-crested weirs with vertical upstream walls and sharpcrested comers.

A contracted broad-crested weir is one where the weir width is smaller than that of the channel. Compared to the suppressed broad-crested weirs, the contracted one has not been studied adequately yet. Hall (1972) analyzed discharge characteristics of broad crested weirs using boundary layer theory. $\mathrm{He}$ proposed a theoretical relation for the discharge over the contracted broadcrested weirs. Muralidhar (1965) conducted some studies on free flow over broad-crested weirs with contractions. Based on a semi-theoretical approach, a discharge relation for flow over suppressed and contracted broadcrested weir has been presented by Ranja Raju and Ahmed (1973).

Negm and. Alshaikh (1997) investigated the characteristics of flow over contracted broad-crested weirs for different contraction ratios in the range $0.508 \leq \mathrm{b} / \mathrm{B} \leq 1.0$ at constant $\mathrm{P} / \mathrm{L}=0.375$ with $0,1 \leq h_{w} / L<0.5$ (b being the width of the contracted weir, $B$ is the channel width, $P$ is the height of the weir, $L$ is the length of the weir and $h_{w}$ is the head of water above the weir). They developed an expression for estimating the discharge coefficient and the velocity coefficient. Saleh et al. (1998) extended the stiddy of Negm and Alshaikh by 
testing broad-crested weirs of $b / B=0.607$ and different $P / L$ in the range of 0.375 to 0.50 .

The characteristics of simultaneous flow over broad-crested weir combined with box smooth culvert of sharp-edges both at entrance and exit are investigated in this study. A prediction equation is developed in terms of the flow, boundary and geometrical parameters of the structure using the multiple linear regression.
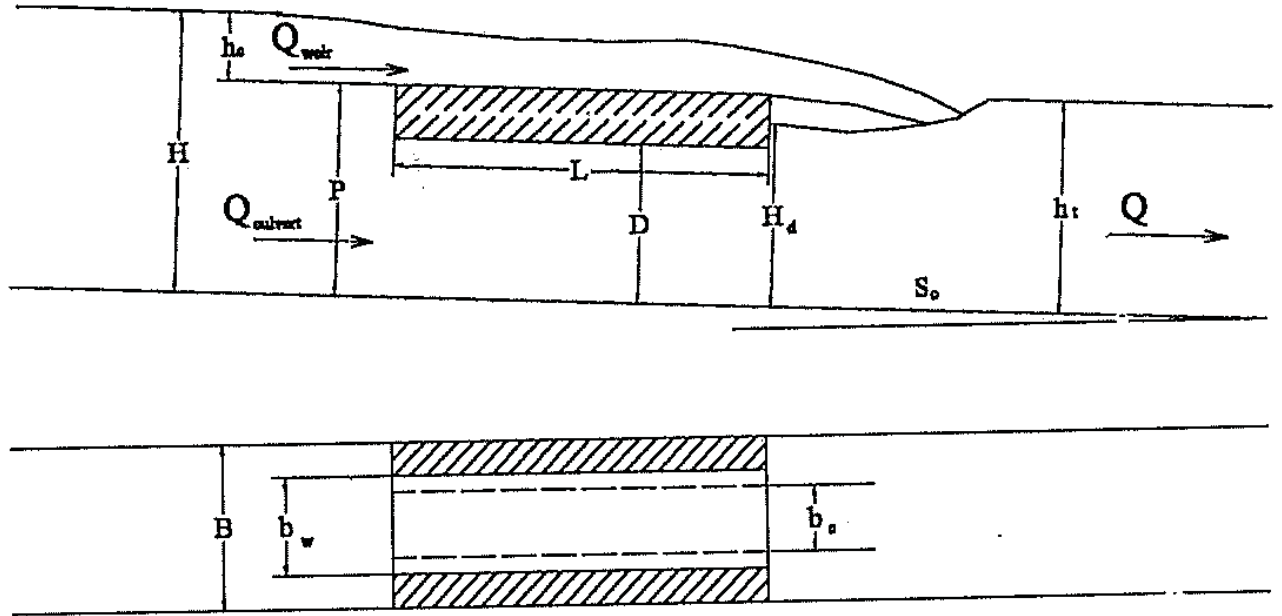

Figure 1. Definition sketch for simultaneous flow through culvert and over broad-crested weir

\section{Theoretical Background}

Figure 1 shows a definition sketch for the proposed structure with the symbols of variables defined as follows: density of water, $\rho$, gravitational acceleration, $\mathrm{g}$, the bottom slope, $\mathrm{S}_{\mathrm{o}, \mathrm{t}}$ he combined discharge of the structure, $Q$, the head of water over the broad-crested weir, $\mathrm{h}_{\mathrm{w}}$, head of water at inlet of the culvert, $\mathrm{H}$, the height of the culvert barrel, $\mathrm{D}$, the depth just downstream the culvert, $\mathrm{H}_{\mathrm{d}}$, the tailwater depth downstream the culvert, $\mathrm{H}_{\mathrm{t}}$, the width of the weir, $\mathrm{b}_{\mathrm{w}}$, the width of the culvert vent, $b_{c}$, the flume width, $B$, the length of the culvert, $L$, and the weir height $p$.

Thus the functional form for the flow rate can be written as follows:

$\left(\begin{array}{l}\rho, g, S_{o}, Q, h_{w}, H, D, H_{d}, H_{t}, b_{w}, \\ b_{c}, L, B, P\end{array}\right)=0(1)$
The following form could be written using the principles of the dimensional analysis:

$\frac{Q}{D^{2} \sqrt{g D}}=f\left(\begin{array}{l}S_{o}, \frac{h_{w}}{D}, \frac{H}{D}, \frac{H_{d}}{D}, \frac{H_{t}}{D}, \frac{b_{w}}{D}, \\ \frac{b_{c}}{D}, \frac{L}{D}, \frac{B}{D}, \frac{P}{D}\end{array}\right)$

The bottom slope, $S_{0}$, the height of the culvert, $\mathrm{D}$, the length of the culvert, $\mathrm{L}$, the weir height, $P$, and the flume width, $B$, are all kept constants during the experimental work, In Eq.(2), the effect of viscosity is neglected as the temperature was mostly constant. The effect of $\mathrm{H}_{d} / \mathrm{D}$ could be neglected as $\mathrm{H}_{d}$ is a function of $\mathrm{H}_{t}$. Taking $\mathrm{H}_{\mathrm{t}} / \mathrm{D}$ equals $S$ to denote the submergence ratio. The effect of $h_{\mathrm{v}}$ is included in H. Eq.(2) can be simplified as follows:

$\frac{Q^{\prime}}{D^{2} \sqrt{g D}}=f\left(\frac{H}{D}, \frac{b_{w}}{D}, \frac{b_{c}}{D}, S\right)$ 
The non-dimensional discharge $\mathrm{Q}_{\mathrm{nd}}=\mathrm{Q} / \mathrm{D}^{2} \sqrt{\mathrm{gD}}$ of equation (3) will be computed using the experimental data and different plots will be prepared to discuss the effect of $H / D, S, b_{w} / D$ and $\mathrm{b}_{\mathrm{c}} / \mathrm{D}$ on it.

\section{Experimental Tests and Setup}

A horizontal rectangular flume $30.5 \mathrm{~cm}$ wide, $31 \mathrm{~cm}$ high and $9.5 \mathrm{~m}$ long is used. The flume is equipped with a tail gate to control the tailwater depth. A centrifugal pump lifts water from underground sump to the flume inlet. Water runs through the flume then returns back to the sump tank via a measuring tank.

The tested model consisted of a contracted broad-crested weir combined with a one vent box culvert with the same total length, $\mathrm{L}$, from entrance to exit of $L=40 \mathrm{~cm}$. The weir width varied from $10 \mathrm{~cm}$ to $18 \mathrm{~cm}$. The height of the culvert barrel was kept constant to $D=6$ $\mathrm{cm}$ while the width of the vent was varying also from $10 \mathrm{~cm}$ to $18 \mathrm{~cm}$. The bottom slope of the structure was kept constant to $S_{0}=0.006$. Appendix 1 shows the details of the experimental data and experimental conditions of the present study. The flow condition was such that the flow at both inlet and outlet of the culvert are submerged and the culvert is flowing full. Always, the approaching discharge to the structure is more than the capacity of the culvert and thus a flow over the weir is expected. The measurements taken include the flow depth at $40 \mathrm{~cm}$ upstream from the culvert and just downstream the culvert to ensure flow over the weir. The tailwater depth was recorded several times for each discharge to account for the effect of submergence.
Discharges were measured by a pre-calibrated V-notch installed in a measuring tank located below flume outlet at its downstream end and is connected directly to underground sump tank. Water depths are measured using a precise point gauge (up to $\pm 0.1 \mathrm{~mm}$ accuracy) mounted on a carriage.

\section{Analysis and Discussions}

The non-dimensional discharge, $Q_{n d}$, given by equation (3) was evaluated using the experimental data. The relationships between $Q_{n d}$ and $H / D$ in accordance with Eq.(3) were plotted in Figures 2, 3 and 4 with one parameter rather than $\mathrm{H} / \mathrm{d}$ as third parameter keeping the other two unchanged. Figure 2 presents the relationships between $Q_{n d}$ and $H / D$ at constant $b_{w} / D=1.4$ and $S$ is increasing from 3 in Fig.2a to 4 in Fig.2d with bc/d as third parameter having values of $1.667,2.0$, $2.333,2.667$ and 3.0. It is clear that the values of $Q_{n d}$ increase with the increase of $H / D$ at fixed values of $S, b_{w} / D$ and $b_{d} / D$. This is because the head upstream the inlet is a major contribution of the differential head affects the discharge. At constant $\mathrm{H} / \mathrm{D}$, it is observed that increasing the ratio $b_{d} / D$, causes a corresponding increasing in the $\mathrm{Q}_{\mathrm{nd}}$ which means that wider vents at conistant height pass more discharges. Particularly, e.g. in Fig.2a, the $Q_{\text {nd }}$ line for $b / D=3.0$ is higher than that for $b_{d} / D=2.667$ and more higher than that for 2.333 ,..etc.

Similarly, Figure 3 shows the relationship between $Q_{n d}$ and $H / D$ at constant values of $b_{c} / D=3.0$ and $S=3$, 3.667 and 4.0 with $b_{w} / D$ as third parameter having values of $1.8,2.2,2.6$ and 3.0. As discussed above, the discharge increases with the increase of 

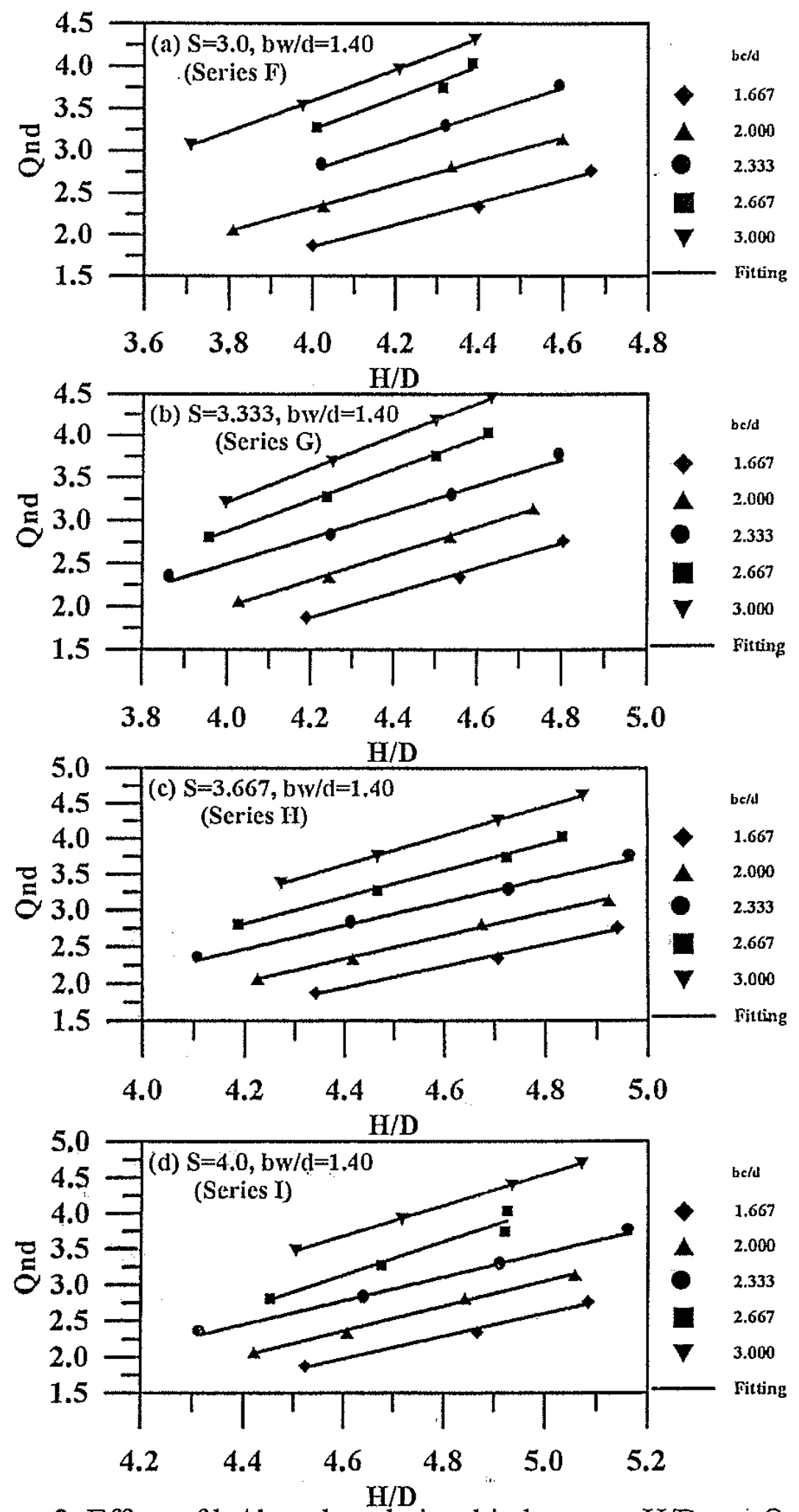

Figure 2. Effect of $b_{d} / d$ on the relationship between $H / D$ and $Q_{n d}$ 

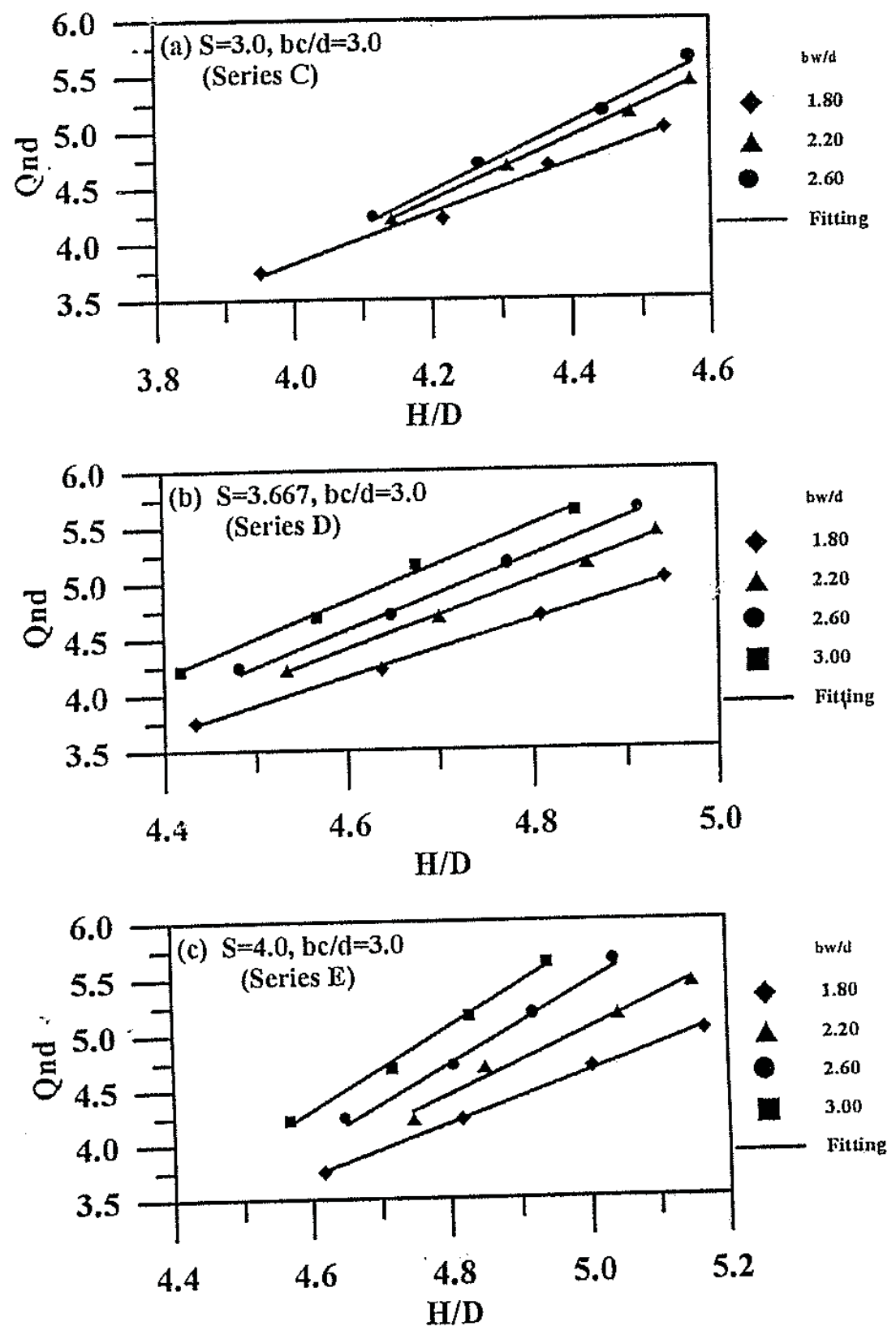

Figure 3. Effect of $b_{w} / d$ on the relationship between $4 / D$ and $Q_{n d}$ 

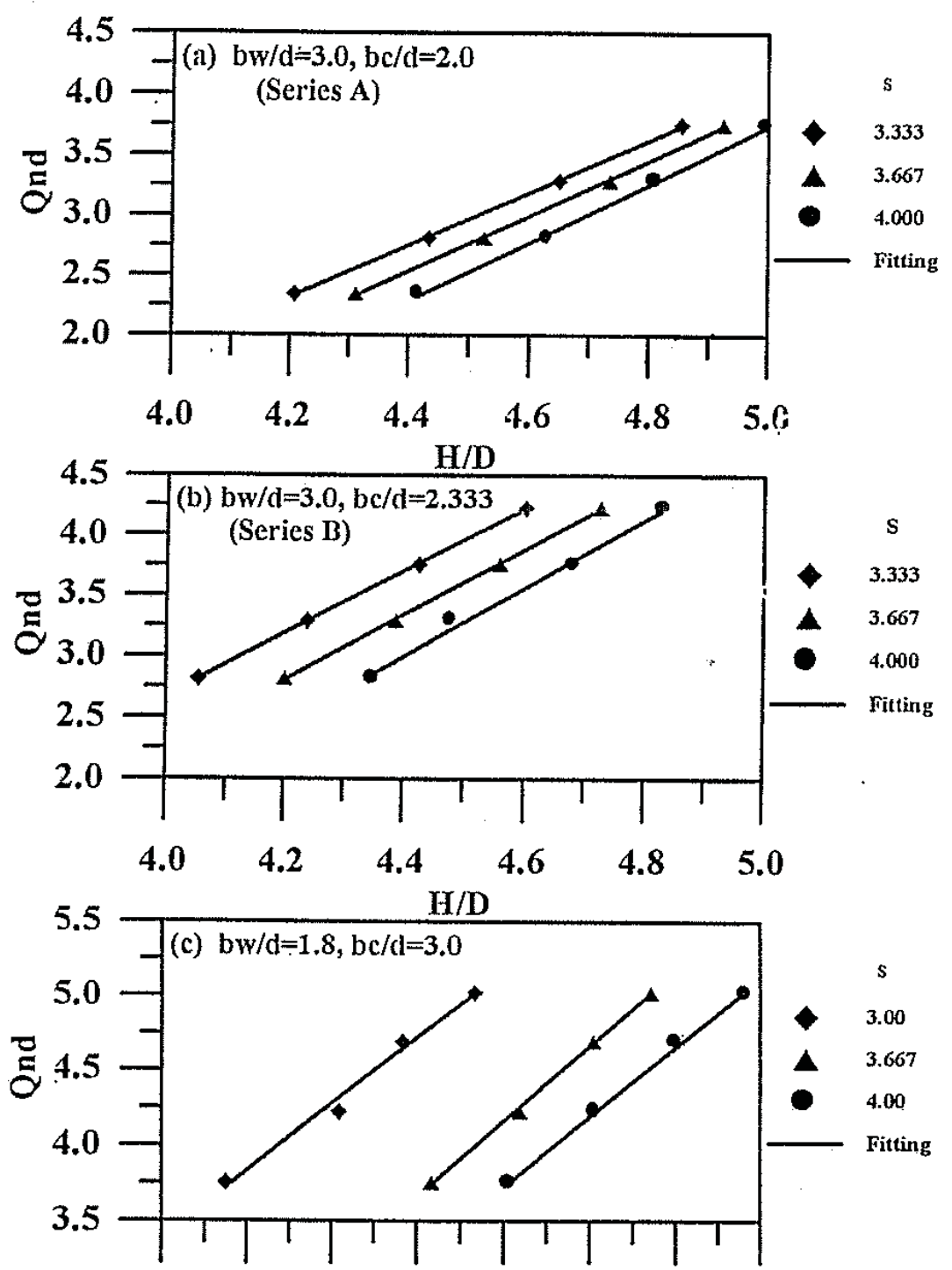

\section{$\begin{array}{llllllll}3.8 & 4.0 & 4.2 & 4.4 & 4.6 & 4.8 & 5.0 & 5.2\end{array}$}

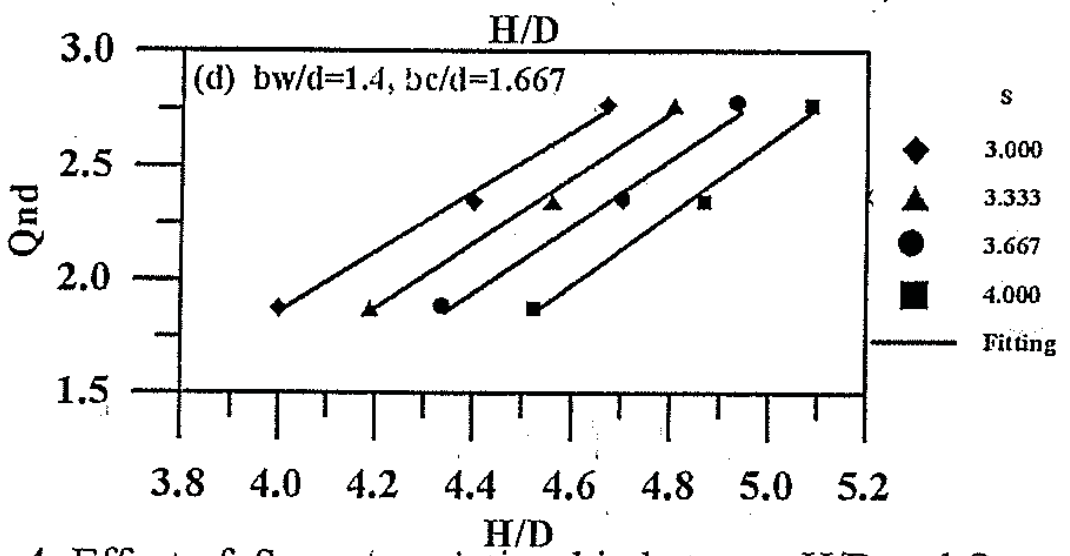

Figure 4. Effect of $\mathrm{S}$ on ihe relationship between H/D and $\mathrm{Q}_{\mathrm{nd}}$ 
$b_{w} / D$, it means that for constant $d$ the more wider the weir the more discharge will be.

Figure 4 shows the relationship between $Q_{\text {nd }}$ and $\mathrm{H} / \mathrm{d}$ for constant values of $b_{w} / D$ and $b_{c} / D$ with $S$ as third parameter having values of $3.0,3.333$, 3.667 and 4.0 . It is clear that increasing the submergence causes a decrease in the discharge because of the increase of downstream water level results a backwater yielding a smaller differential head on the culvert and consequently, the discharge is reduced. Particularly, in Figure $4 \mathrm{~b}$, the line having $S=4.0$ is lower than the line having $S=3.333$.

\section{Prediction of Discharge}

One main point in dealing with discharge measurement structures, is the determination of discharge. The discharge could be predicted if the measurements were used to calibrate a properly regression model. Many models were tested in order to select the most valid one. The model that gives the best results is;

$$
\begin{aligned}
& \mathrm{Q}_{n d}=-0.074+0.225\left(\frac{\mathrm{H}}{\mathrm{D}}\right)^{2}-1.059 \mathrm{~S}+ \\
& 1.33\left(\frac{\mathrm{b}_{\mathrm{w}}}{\mathrm{D}}\right)+0.819\left(\frac{\mathrm{b}_{\mathrm{c}}}{\mathrm{D}}\right)-2.329\left(\frac{\mathrm{b}_{\mathrm{w}}}{\mathrm{b}_{\mathrm{c}}}\right)
\end{aligned}
$$

Equation (4) has a coefficient of determination of 0.973 and standard error of estimate $=0.177$. Figure 5 shows the comparison between the values of $Q_{n d}$ from measurements and the predicted values from Eq.(4). Figure 6 shows the comparison between the prediction of Eq.(4) and the measured values for series $F$ as a typical example. The predicted values are very close to the measured ones with a mean relative error of 0.039 .

\section{Conclusions}

An experimental investigation was conducted concerning the discharge characteristics of simultaneous flow over broad-crested weirs and through box culverts. It was found that the relative upstream head $\mathrm{H} / \mathrm{D}$, the submergence ratio $\mathrm{S}$, the weir width ratio $b_{w} / D$, culvert width ratio $b_{d} / D$ and the weir width/culvert width ratio $b_{w} / b_{c}$ are the main factors affecting the dimensionless discharge. The discharge always is the main factor affecting the structure volume, it increases with the increase of $H / D$ and decreases with the increase of $S$ assuming all other parameters are constants. However, at fixed values of $\mathrm{H} / \mathrm{D}$ and $\mathrm{S}$, the discharge increases with the increase of either $b_{w} / D$ and/or $b_{c} / D$. Non-dimensional discharge prediction equation was developed to predict the discharge of the simultaneous flow over the broad-crested weir and through the box culvert. The prediction of the equation agreed well with the measurements against a percentage mean relative error of less than $4 \%$.

\section{Referencès}

1- Ackers, A., White, W.R., Perkins, J.A. and Harrison, A.J. (1978), "Weirs "and Flumes for Flow Measurements", "Jöhr Willey "\&" Sons, New York, pp. 133-166.

2-'Benson, M.A. (1968), "Measurement of " Peak "Discharge by Indirect Methods"; WMO No. 225, TP.119, Technical Note No.90, Geneva, Switherland.

3- Bodhaine,

G.L. (1968), "Meassurement of Peak Discharge at Culverts" by Indirect Methods" U.S. Geological Survey, Techniques of 


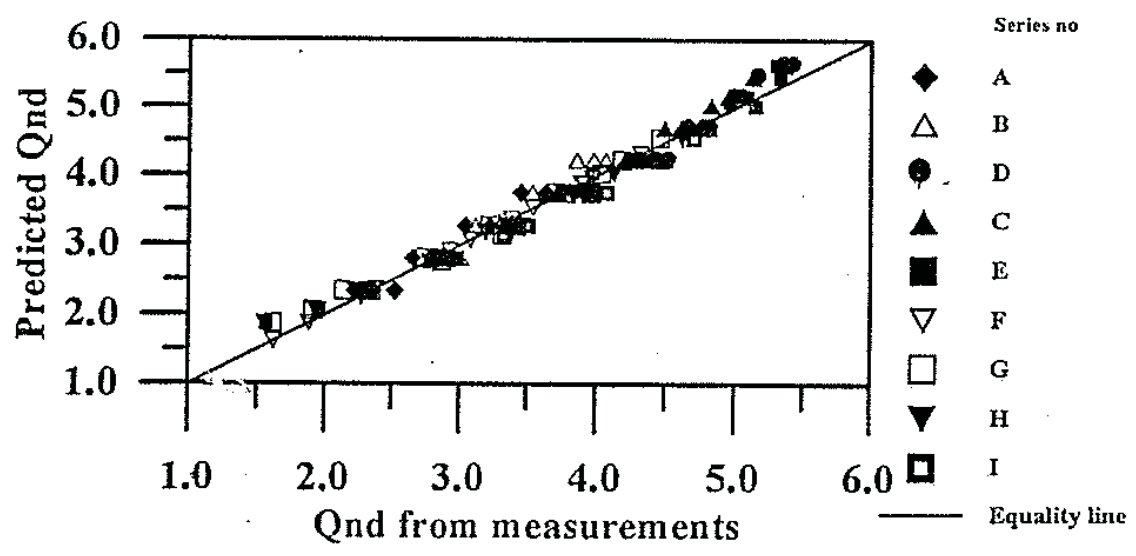

Figure 5. Comparison between $\mathrm{Q}_{\text {nd }}$ from measuremeits and $Q_{\text {nd }}$ from Eq.(4) for all series

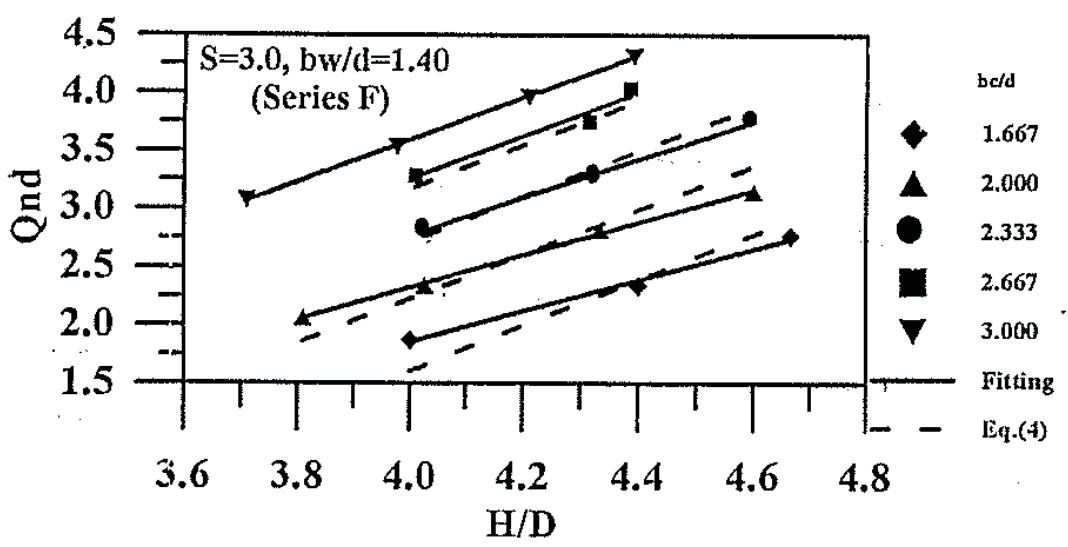

Figure 6. Comparison between $\mathrm{Q}_{\mathrm{nd}}$ from measurements and $\mathrm{Q}_{\text {nd }}$ from Eq.(4) 
Water Resources Investigations, Book 3, Chap. A3, Washington, reprinted 1976.

4- Bos, M.G., Editor, (1976), "Discharge Measurement Structures", Oxford \& IBH publishing Co., New Delhi.

5- Bos, M.G., Replogle, J.A. and Clemmens, J.A. (1984), "Flow Measuring Flumes For Open Channels Systems", John Wiley \& Sons, Inc., New York, N.Y.

6- British Standard Institution, BSI (1965), "Thin-plate weirs and Venturi. flumes, in methods of measurement of liquid flow in open channel", Part 4A, BSI 3680, BSI, London, 1965.

7- Carter, R.W. (1957), "Computation of Peak Discharge at Culverts", U.S. Geological Survey, Circular 376.

8- Chow, V.T. (1959), "Open Channel Hydraulics", McGraw-Hill Int. Book Co., Tokyo, Japan.

9- El-Kateb, M.H. (1974), "Flow Characteristics Over Broad-Crested Weirs", Bulletin of the Faculty of Engineering, Cairo University, Giza, Egypt, Paper No. 17, pp. 1-12.

10- French, J.L. (1955), "Hydraulic Characteristics of Commonly Used Pipes Entrances", First Progress Report on Hydraulics of Short Pipes, U.S. National Bureau of Standards, Report 4444, Dec. 28.

11- French, J.L. (1956), "Pressure and Resistance Characteristics of a Model Pipe Culvert", Second Progress Report on Hydraulics of Culverts, U.S. National Bureau of Standards, Report 4911, Oct. 29.

12- French," J.L. (1957), "Effect of Approach Channel Characteristics on Model Pipe Culvert Operation", Third Progress Report on Hydraulics of Culverts, U.S. National Bureau of Standards, Report 5306, June 3.
13- French, R.H.(1985), "Open Channel Hydraulics", McGraw Hill Book Company, New York.

14- Hager, W.H. and Schwalt, M. (1994), "Broad-Crested Weir", J. Irrigation and Drainage Eng., ASCE, Vol. 120, No. 1, pp.13-25; Disc., Vol. 121, No.2, 1995, pp.222-226.

15- Hall, G.W. (1972), "Discharge Characteristics of Broad-Crested weirs Using Boundary Layer Theory", Proc. Inst. of Civil Eng., Vol.22, London, England, pp.177190.

16- Herschy, R.W. (1978), "Hydrometery", John Wile \& Sons, New York.

17- Mavis, F.T. (1942), The Hydraulics of Culverts", The Pennsylvania State College, Engineering Experiment station, Bulletin 56, Oct. 1.

18- Li, W-H. and Patterson, C.C. (1956), "Free Outlets and SelfPriming Action of Culverts", Paper 1009, Proc. ASCE, Journal of Hydraulics Div., no. HY3, pp.1-22, June.

19- Moss, W.D. (1972), "Flow Separation at the Upstream Edge of a Square-Edged Broad-Crested Weir", J. Fluid Mechanics, Vol. 52, No. 2, pp. 307-320.

20- Muralidhar, D. (1965), "Some Studies on Free Flow Over Weirs of Finite Crest Width", Ph.D. Diss., India Inst. of Science, Bangalore, India.

21- Negm, A.M. and Alshaikh, A.(1997), "Characteristics of Flow Over Contracted Broad-Crested Weirs", Engineering Bulletin for Civil Engineering, Vol.32, No.3, Faculty 
of Engineering, Ain Shams University, Cairo, Egypt, pp.227-247.

22- Ranja Raju, K.G. and Ahmed, I. (1973), "Discharge Characteristics of Suppressed and Contracted BroadCrested Weirs", J. Irrigation and Power, India, Vol. 30, No. 4, pp.157166.

23- Ramamurthy, A:S., Tim, U.S. and Rao, M.V.J. (1988), "Characteristics of Square-Edged Broad-Cresied Weirs", J. Irrigation and Drainage Eng., ASCE, Vol. 11! No. 1, pp.6173.

24- Rao, N.S.L. and Rao, M.V.J. (1973), "Characteristics of Hydrofoil Weirs", J. Hydraulic Eng. Div., ASCE, Vol. 99, No. 2, pp. 259-281.

25- Replogle, J.A. (1978), "Flumes and Broad-Crested Weirs: Mathematical Modeling and Laboratory Ratings", in "Flow Measurements of Fluids", H.H. Dijstalberger and E.E. Spenser, editors, North Holland Publishing Co., Amesterdam, the Netherlands, pp. 321-328.

26- Saleh, O.K., Alshaikh, A. and Negm, A.M. (1998), "Effect Of Relative Height On Characteristics of Free Flow Over Contracted Broad-Crested Weirs", Engineering Res. Journal, Helwan University, Faculty of Engineering, Mataria, Cairo, Egypt, Vol.60, Dec. pp.161172.

27- Shoemaker, R.H. and Clayton, L.A. (1953), "Model Studies of Tapered Inlets for Box Culverts", In Culvert Hydraulics, Highway Research Board, Research Report 15-B, Washington, D.C., pp.1-45.

28- Straub, L.G. and Morris, M.H. (1950), "Hydraulic Data Comparison of Concrete and Corrugated Metal
Culvert Pipes", University of Minnesota. St. Anthony Falls Hydraulics Laboratory, Technical Paper 3, Series B, July.

29- Straub, L.G., and Morris, M.H. (1950), "Hydraulic Tests on Concrete Culvert Pipes", University of Minnesota. St. Anthony Falls Hydraulics Laboratory, Technical Paper 4, Series B, July.

30- Straub, L.G. and Morris, M.H. (1950), "Hydraulic Tests on Corrugated Metal Culvert Pipes", University of Minnesota. St. Anthony Falls Hydraulics Laboratory, Technical Paper 5, Series B, July.

31- Straub, L.G., Anderson, A.G. and Bowers, C.E. (1953), "Effect Inlet Design on Capacity of Culverts on Steep Slopes", University of Minnesota. St. Anthony Falls Hydraulics Laboratory, Project Report No. 37.

32- Straub, L.G., Anderson, A.G. and Bowers, C.E. (1953), "Importance of Inlet Design on Culverts Capacity", In Culvert Hydraulics, Highway Research Board, Research Report 15-B, Washington, D.C., p̂p.53-67.

33- "' Surya Rao, S. and Shukla, M.K. (1971), "Characteristics of Flow Over Weirs of Finite Crest Width", J. Hy"draulic Eng. Div., ASCE, Vol. 97, No. 11, pp. 1807-1815.

34- "Swamee, P.K. (1988), "Generalized rectangular weirs equations", Proc. ASCE, J. Hydraulic Engineering, Vol. 114, No. 8, pp. 945-949.

35- ' USBR (1967), "Water Measurement Manual", Water Resources Technical Publications, United States Department of Interior, 
Bureau of Reclamation, Denver, Colorado, reprinted in 1984.

36- Woodburn, J.G. (1932), "Tests on Broad-Crested Weirs", Trans. ASCE, Vol. 96, pp. 387-408.

37- Yarnell, D.L., Nagler, F.A. and Woodward, S.M. (1926), "Flow of Water Through Culverts", University of Iowa, Studies in Engineering, Bulletin 1.

\section{Notations}

The following symbols are used in the present paper

$b_{w}$ is the width of the contracted broadcrested weir,

$b_{c}$ is the width of the culvert vent,

$B$ is the channel width,

$D$ is the height of the culvert,

$\mathrm{g}$ is the gravitational acceleration,

$h_{w}$ is the head of water above the weir,
$\mathrm{H}$ is the depth of water $40 \mathrm{~cm}$ upstream the culvert inlet,

$\mathrm{H}_{d}$ is the depth of water just downstream of the culvert,

$\mathrm{H}_{\mathrm{t}}$ is the tailwater depth downstream the culvert,

$L$ is the length of the weir or the length of the culvert,

$P$ is the height of the weir,

$Q$ is the combined discharge of the structure,

$\mathrm{Q}_{\mathrm{c}}$ is the discharge through culvert,

$\mathrm{Q}_{\mathrm{nd}}$ is combined the discharge,

$\mathrm{Q}_{\mathrm{w}}$ is the discharge over the weir,

$S$ is the submergence ratio,

$\mathrm{S}_{\mathrm{o}}$ is the bottom slope,

$\mu$ is the dynamic viscosity of water and $\rho$ is the density of water.

\section{Appendix 1}

Experimental conditions and experimental data of the present study

$\begin{array}{lcccccccc}\text { Series } & b_{w}(m) & b_{c}(m) & H / D & Q_{n d} & S & b_{w} / D & b_{d} / D & b_{w} / b_{c} \\ \text { A1 } & 0.180 & 0.120 & 4.100 & 2.347 & 3.000 & 3.000 & 2.000 & 1.500 \\ \text { A.1 } & 0.180 & 0.120 & 4.782 & 3.755 & 3.000 & 3.000 & 2.000 & 1.500 \\ \text { A1 } & 0.180 & 0.120 & 4.335 & 2.816 & 3.000 & 3.000 & 2.000 & 1.500 \\ \text { A1 } & 0.180 & 0.120 & 4.567 & 3.286 & 3.000 & 3.000 & 2.000 & 1.500 \\ \text { A2 } & 0.180 & 0.120 & 4.312 & 2.347 & 3.667 & 3.000 & 2.000 & 1.500 \\ \text { A2 } & 0.180 & 0.120 & 4.525 & 2.816 & 3.667 & 3.000 & 2.000 & 1.500 \\ \text { A2 } & 0.180 & 0.120 & 4.733 & 3.286 & 3.667 & 3.000 & 2.000 & 1.500 \\ \text { A2 } & 0.180 & 0.120 & 4.923 & 3.755 & 3.667 & 3.000 & 2.000 & 1.500 \\ \text { A3 } & 0.180 & 0.120 & 4.812 & 3.286 & 4.000 & 3.000 & 2.000 & 1.500 \\ \text { A3 } & 0.180 & 0.120 & 4.630 & 2.816 & 4.000 & 3.000 & 2.000 & 1.500 \\ \text { A3 } & 0.180 & 0.120 & 4.417 & 2.347 & 4.000 & 3.000 & 2.000 & 1.500 \\ & & & & & & & & \\ \text { B1 } & 0.180 & 0.140 & 3.890 & 2.816 & 3.000 & 3.000 & 2.333 & 1.286 \\ \text { B1 } & 0.180 & 0.140 & 4.303 & 3.755 & 3.000 & 3.000 & 2.333 & 1.286 \\ \text { B1 } & 0.180 & 0.140 & 4.482 & 4.224 & 3.000 & 3.000 & 2.333 & 1.286 \\ \text { B1 } & 0.180 & 0.140 & 4.100 & 3.286 & 3.000 & 3.000 & 2.333 & 1.286 \\ \text { B2 } & 0.180 & 0.140 & 4.200 & 2.816 & 3.667 & 3.000 & 2.333 & 1.286 \\ \text { B2 } & 0.180 & 0.140 & 4.387 & 3.286 & 3.667 & 3.000 & 2.333 & 1.286 \\ \text { B2 } & 0.180 & 0.140 & 4.558 & 3.755 & 3.667 & 3.000 & 2.333 & 1.286 \\ \text { B2 } & 0.180 & 0.140 & 4.725 & 4.224 & 3.667 & 3.000 & 2.333 & 1.286 \\ \text { B3 } & 0.180 & 0.140 & 4.683 & 3.755 & 4.000 & 3.000 & 2.333 & 1.286 \\ \text { B3 } & 0.180 & 0.140 & 4.350 & 2.816 & 4.000 & 3.000 & 2.333 & 1.286 \\ \text { B3 } & 0.180 & 0.140 & 4.833 & 4.224 & 4.000 & 3.000 & 2.333 & 1.286\end{array}$


Mahmoud S. Mohamed

\begin{tabular}{|c|c|c|c|c|c|c|c|c|}
\hline $\begin{array}{l}\text { Series } \\
\mathrm{Cl}\end{array}$ & $\begin{array}{l}b_{w}(m) \\
0.108\end{array}$ & $\begin{array}{l}b_{c}(m) \\
0.180\end{array}$ & $\begin{array}{c}\text { H/D } \\
4.533\end{array}$ & $\begin{array}{c}Q_{\text {nd }} \\
5.022\end{array}$ & $\begin{array}{c}\mathrm{S} \\
3.000\end{array}$ & $\begin{array}{c}\mathrm{b}_{\mathrm{w}} / \mathrm{D} \\
1.800\end{array}$ & $\begin{array}{c}b_{0} / D \\
3.000\end{array}$ & $\begin{array}{c}b_{w} / b_{c} \\
0.600\end{array}$ \\
\hline $\mathrm{C} 1$ & 0.108 & 0.180 & 4.367 & 4.694 & 3.000 & 1.800 & 3.000 & 0.600 \\
\hline $\mathrm{Cl}$ & 0.108 & $0.180^{\circ}$ & 3.950 & 3.755 & 3.000 & 1.800 & 3.000 & 0.600 \\
\hline $\mathrm{C} 1$ & 0.108 & 0.180 & 4.217 & 4.224 & 3.000 & 1.800 & 3.000 & 0.600 \\
\hline $\mathrm{C} 2$ & 0.132 & 0.180 & 4.572 & 5.445 & 3.000 & 2.200 & 3.000 & 0.733 \\
\hline $\mathrm{C} 2$ & 0.132 & 0.180 & 4.483 & 5.163 & 3.000 & 2.200 & $: 3.000$ & 0.733 \\
\hline $\mathrm{C} 2$ & 0.132 & 0.180 & 4.308 & 4.694 & 3.000 & 2.200 & 3.000 & 0.733 \\
\hline $\mathrm{C} 2$ & 0.132 & 0.180 & 4.142 & 4.224 & 3.000 & 2,200 & 3.000 & 0.733 \\
\hline $\mathrm{C} 3$ & 0.156 & 0.180 & 4.448 & 5.163 & 3.000 & 2.600 & 3.000 & 0.867 \\
\hline $\mathrm{C} 3$ & 0.156 & 0.180 & 4.272 & 4.694 & 3.000 & 2.600 & 3.000 & 0.867 \\
\hline C3 & 0.156 & 0.180 & 4.117 & 4.224 & $3.00,0^{-1}$ & --2.600 & 3.000 & 0.867 \\
\hline $\mathrm{C} 3$ & 0.156 & 0.180 & 4.575 & 5.632 & 3.000 & 2.600 & 3.000 & 0.867 \\
\hline$D 1$ & 0.108 & 0.180 & 4.808 & 4.694 & 3.667 & 1.800 & 3.000 & 0.600 \\
\hline D1 & 0.108 & 0.180 & 4.433 & 3.755 & 3.667 & 1.800 & 3.000 & 0.600 \\
\hline D1 & 0.108 & 0.180 & 4.637 & 4.224 & 3.667 & 1.800 & 3.000 & 0.600 \\
\hline D1 & 0.108 & 0.180 & 4.942 & 5.022 & 3.667 & 1.800 & 3.000 & 0.600 \\
\hline $\mathrm{D} 2$ & 0.132 & 0.180 & 4.533 & 4.224 & 3.667 & 2.200 & 3.000 & 0.733 \\
\hline $\mathrm{D} 2$ & 0.132. & 0.180 & 4.700 & 4.694 & 3.667 & 2.200 & 3.000 & 0.733 \\
\hline $\mathrm{D} 2$ & 0.132 & 0.180 & 4.933 & 5.445 & 3.667 & 2.200 & 3.000 & 0.733 \\
\hline $\mathrm{D} 2$ & 0.132 & 0.180 & 4.858 & 5.163 & 3.667 & 2.200 & 3.000 & 0.733 \\
\hline D3 & 0.156 & 0.180 & 4.650 & 4.694 & 3.667 & 2.600 & 3.000 & 0.867 \\
\hline D3 & 0.156 & 0.180 & 4.917 & 5.632 & 3.667 & 2.600 & 3.000 & 0.867 \\
\hline D3 & 0.156 & 0.180 & 4.775 & 5.163 & 3.667 & 2.600 & 3.000 & 0.867 \\
\hline D3 & 0.156 & 0.180 & 4.483 & 4.224 & 3.667 & 2.600 & 3.000 & 0.867 \\
\hline D4 & 0.180 & 0.180 & 4.417 & 4.224 & 3.667 & 3.000 & 3.000 & 1.000 \\
\hline D4 & 0.180 & 0.180 & 4.567 & 4.694 & 3.667 & 3.000 & 3.000 & 1.000 \\
\hline D4 & 0.180 & 0.180 & 4.675 & 5.163 & 3.667 & 3.000 & 3.000 & 1.000 \\
\hline $\mathrm{D} 4$ & 0.180 & 0.180 & 4.847 & 5.632 & 3.667 & 3.000 & 3.000 & 1.000 \\
\hline E1 & 0.108 & 0.180 & 5.167 & 5.022 & 4.000 & 1.800 & 3.000 & 0.600 \\
\hline E1 & 0.108 & 0.180 & 5.003 & 4.694 & 4.000 & 1.800 & 3.000 & 0.600 \\
\hline E1 & 0.108 & 0.180 & 4.617 & 3.755 & 4.000 & 1.800 & 3.000 & 0.600 \\
\hline E1 & 0.108 & 0.180 & 4.817 & 4.224 & 4.000 & 1.800 & 3.000 & 0.600 \\
\hline E2 & 0.132 & 0.180 & 5.042 & 5.163 & 4.000 & 2.200 & 3.000 & 0.733 \\
\hline E2 & 0.132 & 0.180 & 4.850 & 4.694 & 4.000 & 2.200 & 3.000 & 0.733 \\
\hline $\mathrm{E} 2$ & 0.132 & 0.180 & 4.747 & 4.224 & 4.000 & 2.200 & 3.000 & 0.733 \\
\hline E2 & 0.132 & 0.180 & 5.150 & 5.445 & 4.000 & .2 .200 & 3.000 & 0.733 \\
\hline E3 & 0.156 & 0.180 & 5.042 & 5.632 & 4.000 & 2.600 & 3.000 & 0.867 \\
\hline E3 & 0.156 & 0.180 & 4.808 & 4.694 & 4.000 & 2.600 & 3.000 & 0.867 \\
\hline E3 & 0.156 & 0.280 & 4.650 & 4.224 & 4.000 & 2.600 & 3.000 & 0.867 \\
\hline E3 & 0.156 & 0.180 & 4.925 & 5.163 & 4.000 & 2.600 & 3.000 & 0.867 \\
\hline E4 & 0.180 & 0.180 & 4.717 & 4.694 & 4.000 & 3.000 & 3.000 & 1.000 \\
\hline $\mathrm{E} 4$ & 0.180 & 0.180 & 4.650 & 4.224 & 4.000 & 3.000 & 3.000 & 1.000 \\
\hline $\mathrm{E} 4$ & 0.180 & 0.180 & 4.830 & 5.163 & 4.000 & 3.000 & 3.000 & 1.000 \\
\hline$E 4$ & 0.180 & 0.180 & 4.942 & 5.632 & 4.000 & 3.000 & 3.005 & 1.000 \\
\hline E1 & 0.084 & 0.100 & 4.000 & 1.877 & 3.000 & 1.400 & 1.667 & 0.840 \\
\hline F1 & 0.084 & 0.100 & 4.400 & 2.347 & 3.000 & 1.400 & 1.667 & 0.840 \\
\hline E1 & 0.084 & 0.100 & 4.667 & 2.769 & 3.000 & 1.400 & 1.667 & 0.840 \\
\hline E2 & 0.084 & 0.120 & 3.808 & 2.065 & 3.000 & 1.400 & 2.000 & 0.700 \\
\hline$F 2$ & 0.084 & 0.120 & 4.025 & 2.347 & 3.000 & 1.400 & 2.000 & 0.700 \\
\hline F2 & 0.084 & 0.120 & 4.333 & 2.816 & 3.000 & 1.400 & 2.000 & 0.700 \\
\hline $\mathrm{F} 2$ & 0.084 & 0.120 & 4.600 & 3.145 & 3.000 & 1.400 & 2.000 & 0.700 \\
\hline F3 & 0.084 & 0.140 & 4.025 & 2.816 & 3.000 & 1.400 & 2.333 & 0.600 \\
\hline F3 & 0.084 & 0.140 & 4.325 & 3.286 & 3.000 & 1.400 & 2.333 & 0.600 \\
\hline F3 & 0.084 & 0.140 & 4.600 & 3.755 & 3.000 & 1.400 & 2.333 & 0.600 \\
\hline F4 & 0.084 & 0.160 & 4.008 & 3.286 & 3.000 & 1.400 & 2.667 & 0.525 \\
\hline
\end{tabular}


Characteristics of Simultaneous Flow Over Broad Crested ...

\begin{tabular}{|c|c|c|c|c|c|c|c|c|}
\hline $\begin{array}{l}\text { Series } \\
\text { F4 }\end{array}$ & $\begin{array}{l}b_{w}(m) \\
0.084\end{array}$ & $\begin{array}{c}b_{c}(\mathrm{~m}) \\
0.160\end{array}$ & $\begin{array}{c}\mathrm{H} / \mathrm{D} \\
4.313\end{array}$ & $\begin{array}{c}\mathrm{Qnd}_{\mathrm{nd}} \\
3.755\end{array}$ & $\begin{array}{c}S \\
3.000\end{array}$ & $\begin{array}{c}b_{w} / D \\
1.400\end{array}$ & $\begin{array}{c}b_{c} / D \\
2.667\end{array}$ & $\begin{array}{c}b_{w} / b_{c} \\
0.525\end{array}$ \\
\hline F4 & 0.084 & 0.160 & 4.387 & 4.037 & 3.000 & 1.400 & 2.667 & 0.525 \\
\hline F5 & 0.084 & 0.180 & 3.708 & 3.286 & 3.000 & 1.400 & 3.000 & 0.467 \\
\hline E5 & 0.084 & 0.180 & 3.975 & 3.755 & 3.000 & 1.400 & 3.000 & 0.467 \\
\hline E5 & 0.084 & 0.180 & 4.208 & 4.224 & 3.000 & 1.400 & 3.000 & 0.467 \\
\hline F5 & 0.084 & 0.180 & 4.392 & 4.553 & 3.000 & 1.400 & 3.000 & 0.467 \\
\hline GI & 0.084 & 0.100 & 4.188 & 1.877 & 3.333 & 1.400 & 1.667 & 0.840 \\
\hline $\mathrm{Gl}$ & 0.084 & 0.100 & 4.558 & 2.347 & 3.333 & 1.400 & 1.667 & 0.840 \\
\hline GI & 0.084 & 0.100 & 4.803 & 2.769 & 3.333 & 1.400 & 1.667 & 0.840 \\
\hline G2 & 0.084 & 0.120 & 4.025 & 2.065 & 3.333 & 1.400 & 2.000 & 0.700 \\
\hline $\mathrm{G} 2$ & 0.084 & 0.120 & 4.242 & 2.347 & 3.333 & 1.400 & 2.000 & 0.700 \\
\hline $\mathrm{G} 2$ & 0.084 & 0.120 & 4.533 & 2.816 & 3.333 & 1.400 & 2.000 & 0.700 \\
\hline $\mathrm{G} 2$ & 0.084 & 0.120 & 4.733 & 3.145 & 3.333 & 1.400 & 2.000 & 0.700 \\
\hline G3 & 0.084 & 0.140 & 3.867 & 2.347 & 3.333 & 1.400 & 2.333 & 0.600 \\
\hline G3 & 0.084 & 0.140 & 4.250 & 2.816 & 3.333 & 1.400 & 2.333 & 0.600 \\
\hline G3 & 0.084 & 0.140 & 4.542 & 3.286 & 3.333 & 1.400 & 2.333 & 0.600 \\
\hline G3 & 0.084 & 0.140 & 4.800 & 3.755 & 3.333 & 1.400 & 2.333 & 0.600 \\
\hline GA & 0.084 & 0.160 & 3.953 & 2.816 & 3.333 & 1.400 & 2.667 & 0.525 \\
\hline G4 & 0.084 & 0.160 & 4.237 & 3.286 & 3.333 & 1.400 & 2.667 & 0.525 \\
\hline $\mathrm{G} 4$ & 0.084 & 0.160 & 4.500 & 3.755 & 3.333 & 1.400 & 2.667 & 0.525 \\
\hline G4 & 0.084 & 0.160 & 4.625 & 4.037 & 3.333 & 1.400 & 2.667 & 0.525 \\
\hline G5 & 0.084 & 0.180 & 3.993 & 3.286 & 3.333 & 1.400 & 3.000 & 0.467 \\
\hline G5 & 0.084 & 0.180 & 4.250 & 3.755 & 3.333 & 1.400 & 3.000 & 0.467 \\
\hline G5 & 0.084 & 0.180 & 4.500 & 4.224 & 3.333 & 1.400 & 3.000 & 0.467 \\
\hline G5 & $0.0 B 4$ & 0.180 & 4.633 & 4.553 & 3.333 & 1.400 & 3.000 & 0.467 \\
\hline $\mathrm{HI}$ & 0.084 & 0.100 & 4.342 & 1.877 & 3.667 & 1.400 & 1.667 & 0.840 \\
\hline H1 & 0.084 & 0.100 & 4.707 & 2.347 & 3.667 & 1.400 & 1.667 & 0.840 \\
\hline $\mathrm{H} 1$ & 0.084 & 0.100 & 4.942 & 2.769 & 3.667 & 1.400 & 1.667 & 0.840 \\
\hline $\mathrm{H} 2$ & 0.084 & 0.120 & 4.225 & 2.065 & 3.667 & 1.400 & 2.000 & 0.700 \\
\hline $\mathrm{H} 2$ & 0.084 & 0.120 & 4.417 & 2.347 & 3.667 & 1.400 & 2.000 & 0.700 \\
\hline $\mathrm{H} 2$ & 0.084 & 0.120 & 4.675 & 2.816 & 3.667 & 1.400 & 2.000 & 0.700 \\
\hline $\mathrm{H} 2$ & 0.084 & 0.120 & 4.925 & 3.145 & 3.667 & 1.400 & 2.000 & 0.700 \\
\hline H3 & 0.084 & 0.140 & 4.112 & 2.347 & 3.667 & 1.400 & 2.333 & 0.600 \\
\hline H 3 & 0.084 & 0.140 & 4.417 & 2.816 & 3.667 & 1.400 & 2.3333 & 0.600 \\
\hline H3 & 0.084 & 0.140 & 4.733 & 3.286 & 3.667 & 1.400 & 2.333 & 0.600 \\
\hline $\mathrm{H} 3$ & 0.084 & 0.140 & 4.972 & 3.755 & 3.667 & 1.400 & $2.333^{3}$ & 0.600 \\
\hline $\mathrm{H} 4$ & 0.084 & 0.160 & 4.187 & 2.816 & 3.667 & 1.400 & 2.667 & 0.525 \\
\hline $\mathrm{H} 4$ & 0.084 & 0.160 & 4.467 & 3.286 & 3.667 & 1.400 & 2.667 & 0.525 \\
\hline $\mathrm{HA}$ & 0.084 & 0.160 & 4.725 & 3.755 & 3.667 & 1.400 & 2.667 & 0.525 \\
\hline $\mathrm{H} 4$ & 0.084 & 0.160 & 4.833 & 4.037 & 3.667 & 1.400 & 2.667 & 0.525 \\
\hline H5 & 0.084 & 0.180 & 4.273 & 3.286 & 3.667 & 1.400 & 3.000 & 0.467 \\
\hline H5 & 0.084 & 0.180 & 4.467 & 3.755 & 3.667 & 1.400 & 3.000 & 0.467 \\
\hline $\mathrm{H} 5$ & 0.084 & 0.180 & 4.708 & 4.224 & 3.667 & 1.400 & 3.000 & 0.467 \\
\hline H5 & 0.084 & 0.180 & 4.875 & 4.553 & 3.667 & 1.400 & 3.000 & 0.467 \\
\hline I1 & 0.084 & 0.100 & 4.523 & 1.877 & 4.000 & 1.400 & 1.667 & 0.840 \\
\hline I1 & 0.084 & 0.100 & 4.867 & 2.347 & 4.000 & 1.400 & 1.667 & 0.840 \\
\hline I1 & 0.084 & 0.100 & 5.083 & 2.769 & 4.000 & 1.400 & 1.667 & 0.840 \\
\hline I2 & 0.084 & 0.120 & 4.420 & 2.065 & 4.000 & 1.400 & 2.000 & 0.700 \\
\hline I2 & 0.084 & 0.120 & 4.607 & 2.347 & 4.000 & 1.400 & 2.000 & 0.700 \\
\hline I2 & 0.084 & 0.120 & 4.842 & 2.816 & 4.000 & 1.400 & 2.000 & 0.700 \\
\hline I2 & 0.084 & 0.120 & 5.058 & 3.145 & 4.000 & 1.400 & 2.000 & 0.700 \\
\hline I3 & 0.084 & 0.140 & 4.317 & 2.347 & 4.000 & 1.400 & 2.333 & 0.600 \\
\hline I3 & 0.084 & 0.140 & 4.642 & 2.816 & 4.000 & 1.400 & 2.333 & 0.600 \\
\hline I3 & 0.084 & 0.140 & 4.917 & 3.286 & 4.000 & 1.400 & 2.333 & 0.600 \\
\hline I3 & 0.084 & 0.140 & 5.167 & 3.755 & 4.000 & 1.400 & 2.333 & 0.600 \\
\hline
\end{tabular}


Mahmoud S. Mohamed

\begin{tabular}{llllccccc}
\hline Series & $\mathrm{b}_{\mathrm{w}}(\mathrm{m})$ & $\mathrm{b}_{\mathrm{s}}(\mathrm{m})$ & $\mathrm{H} / \mathrm{D}$ & $\mathrm{Q}_{\mathrm{nd}}$ & $\mathrm{S}$ & $\mathrm{b}_{\mathrm{w}} / \mathrm{D}$ & $\mathrm{b}_{\mathrm{c}} / \mathrm{D}$ & $\mathrm{b}_{\mathrm{w}} / \mathrm{b}_{\mathrm{c}}$ \\
I4 & 0.084 & 0.160 & 4.452 & 2.816 & 4.000 & 1.400 & 2.667 & 0.525 \\
I4 & 0.084 & 0.160 & 4.675 & 3.286 & 4.000 & 1.400 & 2.667 & 0.525 \\
I4 & 0.084 & 0.160 & 4.920 & 3.755 & 4.000 & 1.400 & 2.667 & 0.525 \\
I4 & 0.084 & 0.160 & 4.925 & 4.037 & 4.000 & 1.400 & 2.667 & 0.525 \\
I5 & 0.084 & 0.180 & 4.503 & 3.286 & 4.000 & 1.400 & 3.000 & $0.4 n 7$ \\
I5 & 0.084 & 0.180 & 4.717 & 3.755 & 4.000 & 1.400 & 3.000 & 0.467 \\
I5 & 0.084 & 0.180 & 4.933 & 4.224 & 4.000 & 1.400 & 3.000 & 0.467 \\
I5 & 0.084 & 0.180 & 5.070 & 4.553 & 4.000 & 1.400 & 3.000 & 0.467
\end{tabular}

